SABRAO Journal of Breeding and Genetics

53 (4) 592-608, 2021

http://doi.org/10.54910/sabrao2021.53.4.4

http://sabraojournal.org/

pISSN 1029-7073; eISSN 2224-8978

\title{
AGRONOMIC RESPONSES OF DIVERSE BREAD WHEAT GENOTYPES TO PHOSPHORUS LEVELS AND NITROGEN FORMS IN A SEMIARID ENVIRONMENT
}

\author{
M.A. SWAILAM, S.A.E. MOWAFY, N.Z.A. EL-NAGGAR, \\ and E. MANSOUR* \\ Crop Science Department, Faculty of Agriculture, Zagazig University, 44519 Zagazig, Egypt \\ *Corresponding author email: sayed_mansour_84@yahoo.es \\ Email addresses of co-authors: ma9096976@gmail.com, sabermowafy@outlook.sa, \\ nehalhossin@yahoo.com
}

\begin{abstract}
SUMMARY
Increasing wheat production has become an urgent requirement to cope with rapid population growth and abrupt climate change. The management of phosphorus (P) and nitrogen $(\mathrm{N})$ is one of the most important factors for sustaining and increasing wheat production, particularly in semiarid environments. This 2-year field study, which aimed to investigate the effect of $P$ levels $\left(0,35\right.$, and $70 \mathrm{~kg}_{2} \mathrm{O}_{5} \mathrm{ha}^{-1}$ ) and $\mathrm{N}$ forms (urea, ammonium sulfate, and ammonium nitrate) on the yield attributes of three diverse highyielding commercial wheat cultivars ('Shandawel-1', 'Sids-14', and 'Sakha-95'), was carried out at Om-Elzain Village, Zagazig, Egypt. The results indicated that increasing $P$ levels was accompanied by a substantial increase in all evaluated traits, except spike length, and that high $P$ level (70 kg $\mathrm{P}_{2} \mathrm{O}_{5} \mathrm{ha}^{-1}$ ) was superior. Considerable genetic variation was detected among the evaluated cultivars for all studied traits. Cultivar 'Sakha-95', followed by 'Sids$14^{\prime}$, presented the most vigorous growth and enhancements in most yield components, grain yield, and biological yield. Furthermore, 'Sakha-95' recorded the highest agronomic $P$ use efficiency, followed by cultivar 'Sids-14'. N forms did not significantly affect all of the tested traits except plant height, spike number $\mathrm{m}^{-2}$, and 1000 -grain weight, during both seasons. Ammonium-containing fertilizer (ammonium sulfate and ammonium nitrate) resulted in the highest values for these traits when compared with urea. Accordingly, 'Sakha-95' and 'Sids-14' are recommended for commercial use under high $P$ levels. $N$ forms had a marginally substantial effect on grain yield and its attributes.
\end{abstract}

Keywords: Phosphorus levels, nitrogen forms, wheat cultivars, grain yield and its attributes, agronomic phosphorus use efficiency, principal component analysis

Key findings: All evaluated agronomic traits significantly responded to high $P$ levels (75 kg $\mathrm{P}_{2} \mathrm{O}_{5} \mathrm{ha}^{-1}$ ) and increased. The evaluated wheat cultivars displayed significant differences in all traits with 'Sakha-95' being superior. $\mathrm{N}$ forms had a marginally substantial impact on grain yield and its attributes.

Manuscript received: August 26, 2021; Accepted: November 72021.

(C) Society for the Advancement of Breeding Research in Asia and Oceania (SABRAO) 2021

Communicating Editor: Dr. Gwen Iris Descalsota-Empleo 


\section{INTRODUCTION}

Wheat (Triticum aestivum L.) is one of the most important field crops worldwide. It is a major source of starch and provides substantial amounts of vitamins, protein, phytochemicals, and dietary fiber (Shewry and Hey, 2015). Its total cultivated area is nearly 216 million hectares, which produce approximately 766 million tons of wheat annually (FAO-STAT, 2021). Egypt contributes 1.5 million hectares with an annual production rate of 9 million tons per year to the above acreage. Nevertheless, Egypt is one of the most top importers of wheat, importing almost 10 million tons of wheat every year (FAOSTAT, 2021). Moreover, the gap between consumption and national production is expanding owing to rapid population growth and abrupt climate change (Mansour et al., 2020). Therefore, increasing wheat production has become a crucial prerequisite to cope with current constraints.

Mineral fertilization is performed to sustain and increase wheat production (McDonald et al., 2015). Phosphorus (P) is an essential macronutrient for the successful growth of all plant cells ( $\mathrm{Li}$ et al., 2021). It is involved in numerous vital functions, such as photosynthesis, energy transfer, nutrient movement, protein synthesis, and sugar transformation (Baker et al., 2015). Although $P$ is present at high amounts in the soil, its uptake by plants and its availability are low due to its slow diffusion to the roots and low concentrations in the soil solution (Simpson et al., 2011). Therefore, increasing $P$ rates is required to manage the low availability, recovery, and use efficiency of $P$ (McBeath et al., 2012).

Nitrogen $(\mathrm{N})$ is a major component of amino acids, chlorophyll, energytransfer compounds, and nucleic acids in plant cells (Van-Tol and Armbrust, 2021). It is the most limiting nutrient in crop productivity (Guo et al., 2016). N is virtually deficient in most soils of Africa (Amin, 2011), and increased cropping intensity reduces its availability (Amanullah and Inamullah, 2016).
Consequently, it is required at optimal rates for profitable and sustainable cereal production. However, its excessive application leads to $\mathrm{N}$ leaching, runoff, volatilization, and denitrification, which result in environmental pollution and financial waste. Therefore, careful $\mathrm{N}$ management and utilizing cultivars with high $\mathrm{N}$ use efficiency are critical (Mansour et al., 2017). Genotypes display diverse performance under different environmental conditions (Gracia et al., 2012, Mansour et al., 2018a, b, Attia et al., 2021). Hence, the evaluation of wheat genotypes to identify those with increased efficiency in utilizing mineral nutrients is important for sustainable production in the future (McLaughlin et al., 2011).

The forms of $\mathrm{N}$ fertilizer considerably affect cereal production (Biswas and $\mathrm{Ma}, 2016$ ). Urea is the most popular $\mathrm{N}$ form that has certain benefits in marketing, transporting, and manufacturing over other forms. However, a considerable amount of $\mathrm{N}$ is lost through ammonia volatilization when urea is not incorporated into the soil by tillage, irrigation, or rainfall (Ma et al., 2010). Ammonium sulfate and ammonium nitrate have greater agronomic $\mathrm{N}$ use efficiency than urea (Halvorson et al., 2010). Therefore, among plants fertilized with the three $\mathrm{N}$ forms at the same $\mathrm{N}$ rate, those fertilized with ammonium sulfate and ammonium nitrate produce higher yields (Hafez and Kobata, 2012). The higher environmental and agronomic potential merits of ammonium sulfate than those of other forms come at a higher cost (Amanullah, 2014).

Inappropriate nutrient application poses challenging constraints to increasing wheat productivity in farmer's fields (Khan, 2015). However, information regarding the effect of $P$ level and $\mathrm{N}$ form on the agronomic response of wheat cultivars under irrigated conditions in semiarid environments is limited. Therefore, this study was designed to assess the yield response of diverse wheat cultivars to different $P$ levels and $\mathrm{N}$ forms to identify the appropriate management 
strategy for the improvement of wheat productivity under semiarid conditions.

\section{MATERIALS AND METHODS}

\section{Experimental site and cultural practices}

A field experiment was carried out during the 2017-18 and 2018-19 growing seasons at the area designated for wheat production in Om-Elzain Village, Zagazig, Egypt $\left(30^{\circ} 39^{\prime} \mathrm{N}, \quad 31^{\circ} \quad 23^{\prime} \mathrm{E}\right)$. The experimental soil was clay throughout the profile $(18.9 \%$ sand, $34.2 \%$ silt, and $46.9 \%$ clay) with the $\mathrm{pH}$, electrical conductivity, and organic matter content of $8.21,1.32 \mathrm{dS} \mathrm{m}^{-1}$, and $1.62 \%$, respectively. The levels of the available nutrients $\mathrm{N}, \mathrm{P}$, and $\mathrm{K}$ were 45.6, 12.0, and $215 \mathrm{mg} \mathrm{kg}^{-1}$ soil, respectively. The experimental site is characterized by low precipitation and an arid climate with an annual average rainfall of approximately $70 \mathrm{~mm}$. The monthly minimum temperature, maximum temperature, cumulative growing degree days, relative humidity, and total precipitation for both seasons and 35-year averages (1985 to 2019) are presented in Table 1 . In accordance with the optimal period of wheat growing in Egypt, sowing was performed in the third week of November in both growing seasons. The preceding crop in both seasons was maize. Standard agronomic treatments for wheat production in the region, including irrigation, weed, disease, and pest and control, were followed as recommended.

\section{Studied treatments and experimental design}

Two $P$ levels (35 and $70 \mathrm{~kg} \mathrm{P}_{2} \mathrm{O}_{5} \mathrm{ha}^{-1}$ ) versus the nonadded control, three highyielding commercial cultivars ('Shandawel1', 'Sids-14', and 'Sakha-95') and three N forms (46\% $\mathrm{N}$ urea, $20.5 \% \mathrm{~N}$ ammonium sulfate, and $33.5 \% \mathrm{~N}$ ammonium nitrate) applied at the rate of $190 \mathrm{~kg} \mathrm{~N} \mathrm{ha}^{-1}$ were evaluated. The pedigree and origin of the used wheat cultivars are shown in Table 2.
A spilt-split plot design was applied with three replications. $P$ levels were specified as the main plots, wheat cultivars were randomly distributed into subplots, and $\mathrm{N}$ forms were randomly allocated into subsubplots. Each plot consisted of 12 rows $0.15 \mathrm{~m}$ apart and $5 \mathrm{~m}$ long. The seeding rate was 350 seeds $\mathrm{m}^{-2}$. After sowing and before irrigation, superphosphate (15.5\% $\left.\mathrm{P}_{2} \mathrm{O}_{5}\right)$ at the designated levels was placed at the depth of $5 \mathrm{~cm}$ beside the rows. The used $\mathrm{N}$ amounts (190 kg N ha ${ }^{-1}$ ) were split into equal three doses: $1 / 3$ at sowing, $1 / 3$ after 3 weeks from sowing, and $1 / 3$ at 50 days after sowing (DAS). Furrow irrigation was performed by following the standard practice of the region with approximately $4500 \mathrm{~m}^{3} / \mathrm{ha}$ of water applied in each growing season. Irrigation was applied at sowing, at 25 DAS approximately at the crown root initiation stage, at 55 DAS approximately between the tillering stage and the jointing stage, at 85 DAS at flowering, and at 115 DAS at the dough stage.

\section{Trait measurement}

The flag leaf area $\left(\mathrm{cm}^{2}\right)$ of 10 random plants from the middle rows of each plot was determined at heading by using the following equation: leaf area = leaf length $\times$ maximum leaf width $\times 0.75$. Plant height $(\mathrm{cm})$ was recorded as the distance from the ground surface to the top of the spike, excluding awns, for 10 plants that were randomly selected from each plot at maturity. The spike number was counted in a $0.5 \mathrm{~m}^{2}$ area in each plot. Spike length, spikelet number spike ${ }^{-1}$, and grain number spike ${ }^{-1}$ were measured from 10 randomly selected spikes at each plot. Thousand-grain weight was estimated as the weight of 1000 grains sampled from the harvest of six central rows. In addition, at physiological maturity, six central rows from each plot were manually harvested. The whole harvested plants were weighed to measure biological yield. Subsequently, the grains of the harvested plants were threshed, and then the weight of grain yield was measured and converted into $\mathrm{kg} \mathrm{ha}^{-1}$. 
Table 1. Monthly minimum and maximum temperatures, growing degree day, relative humidity, and total precipitation for both growing seasons (2017-2018 and 2018-2019) and 35-year monthly averages (1985-2019).

\begin{tabular}{|c|c|c|c|c|c|}
\hline Month & Min. Temp. $\left({ }^{\circ} \mathrm{C}\right)$ & Max. Temp. $\left({ }^{\circ} \mathrm{C}\right)$ & GDD $\left({ }^{\circ} \mathrm{C}\right)$ & $\mathrm{RH}(\%)$ & Prec. \\
\hline \multicolumn{6}{|c|}{ First season (2017-18) } \\
\hline November & 17.98 & 22.34 & 604.8 & 67.21 & 15.82 \\
\hline December & 16.08 & 20.18 & 562.1 & 70.42 & 5.27 \\
\hline January & 13.58 & 17.88 & 487.7 & 69.38 & 15.82 \\
\hline February & 13.83 & 19.46 & 466.1 & 71.12 & 10.54 \\
\hline March & 15.14 & 22.59 & 584.9 & 63.64 & 0.00 \\
\hline April & 17.00 & 24.26 & 618.9 & 64.76 & 0.00 \\
\hline May & 20.67 & 27.50 & 746.7 & 66.49 & 0.00 \\
\hline \multicolumn{6}{|c|}{ Second season (2018-19) } \\
\hline November & 19.37 & 23.67 & 645.7 & 65.30 & 15.81 \\
\hline December & 15.63 & 19.24 & 540.4 & 69.01 & 17.44 \\
\hline January & 11.34 & 17.00 & 439.3 & 66.03 & 21.63 \\
\hline February & 12.12 & 17.77 & 418.4 & 69.27 & 5.27 \\
\hline March & 13.34 & 18.88 & 499.5 & 70.16 & 11.09 \\
\hline April & 15.00 & 21.58 & 548.7 & 66.50 & 0.00 \\
\hline May & 19.07 & 27.62 & 723.6 & 61.25 & 0.00 \\
\hline \multicolumn{6}{|c|}{ 35-year average } \\
\hline November & 18.40 & 23.08 & & 67.20 & 12.95 \\
\hline December & 15.00 & 19.36 & & 68.27 & 15.61 \\
\hline January & 12.90 & 17.53 & & 69.01 & 16.96 \\
\hline February & 12.54 & 17.86 & & 68.35 & 18.98 \\
\hline March & 13.57 & 19.62 & & 67.91 & 7.68 \\
\hline April & 15.68 & 22.85 & & 65.37 & 4.37 \\
\hline May & 18.72 & 25.95 & & 65.36 & 0.30 \\
\hline
\end{tabular}

GDD: Growing degree day, RH (\%): Relative humidity, Prec. (mm): Total precipitation

${ }^{*}$ Growing degree day was computed by using the daily minimum temperature and maximum temperature in accordance with the base temperature of $0{ }^{\circ} \mathrm{C}$ (McMaster et al., 2003) and accumulated for each month.

Table 2. Pedigree and origin of the tested wheat cultivars.

\begin{tabular}{llll}
\hline Genotypes & Pedigree & $\begin{array}{l}\text { Year of } \\
\text { release }\end{array}$ & Origin \\
\hline Shandawel-1 & $\begin{array}{l}\text { SITE//MO/4/NAC/TH.AC//3*PVN/3/MIRLO/BUC. } \\
\text { CMSS93B00567S-72Y-010M-010Y-010M-3Y-0M- } \\
\text { OTHY-0SH. }\end{array}$ & 2013 & CIMMYT \\
\hline Sids-14 & $\begin{array}{l}\text { SW8488*2/ KUKUNACGSS01Y00081T-099M- } \\
\text { 099Y-099M-099B-9Y-OB-0SD }\end{array}$ & 2016 & Egypt \\
\hline \multirow{5}{*}{ Sakha-95 } & $\begin{array}{l}\text { PASTOR//SITE/MO/3/CHEN/AEGILOPS } \\
\text { SQUARROSA(TAUS)// }\end{array}$ & & \\
& $\begin{array}{l}\text { BCN/4/WBLL1 (CMSA01Y00158S-040P0Y-040M- } \\
\text { O30ZTM040SY-26M-OY-OSY-0S). }\end{array}$ & 2016 & Egypt \\
\hline
\end{tabular}




\section{Statistical analysis}

The data of the two seasons were subjected to ANOVA appropriate for a split-split plot design to test the influence of individual factors: $P$ rate, wheat cultivars, $\mathrm{N}$ form, and their interactions. The mean differences and their interactions were separated by using the LSD test at the significance level of $P \leq$ 0.05 . Principal component analysis was performed on the averages of the evaluated traits. R software version 4.1.1 was used to perform all analyses. $P$ agronomic efficiency (kg $\left.\mathrm{kg}^{-1}\right)$ was estimated in accordance with $\mathrm{He}$ et al. (2009) as the ratio of (grain yield at Px grain yield at $\mathrm{PO}$ ) to $P$ applied at $\mathrm{Px}$.

\section{RESULTS AND DISCUSSION}

\section{Effect of $P$ levels on the evaluated traits}

In both seasons, $P$ levels exerted a significant effect on all evaluated traits, except for spike length (Tables 3 and 4). The intermediate $P$ level ( $35 \mathrm{~kg} \mathrm{P}_{2} \mathrm{O}_{5} \mathrm{ha}^{-1}$ ) failed to increase plant height, spike length, and spikelet number spike ${ }^{-1}$ but significantly increased all remaining traits compared with the control treatment. Furthermore, all the assessed traits significantly responded to high $P$ levels (70 kg $\mathrm{P}_{2} \mathrm{O}_{5} \mathrm{ha}^{-1}$ ). However, spike length was not significantly affected by $P$ levels. Over the two seasons, high $P$ level increased flag leaf area, plant height, and spikelet number spike ${ }^{-1}$ by $10.39 \%$, $1.21 \%$, and $3.37 \%$, respectively, compared with the control treatment. Likewise, high $P$ level increased the spike number $\mathrm{m}^{-2}$, grain number spike ${ }^{-1}, 1000-$ grain weight, grain yield, and biological yield by $6.83 \%, 7.31 \%, 12.24 \%, 9.31 \%$, and $8.26 \%$, respectively, compared with the control treatment. These improvements could be attributed to the effect of $P$ fertilization; in particular, high levels of $P$ fertilization improved $P$ concentrations in the soil solution, diffusion to the roots, and use efficiency
(Simpson et al., 2011). Consequently, the high level of $P$ considerably boosted photosynthesis, protein synthesis, energy transfer, nutrient movement, and sugar transformation (Baker et al., 2015) and accordingly improved assimilate accumulation, vegetative growth, and yield traits. In this context, McKenzie et al. (2003), Majeed et al. (2014), Deng et al. (2018), and Assefa et al. (2021) illustrated the stimulating and favorable effects of high $P$ levels on the yield attributes of wheat.

\section{Genotypic performance}

Substantial genetic variation was detected among the evaluated cultivars for all studied traits (Tables 3 and 4). The cultivars 'Sakha-95' and 'Sids-14' displayed the highest flag leaf area, plant height, and spike length, whereas 'Shandawel-1' and 'Sakha-95' exhibited the highest spikelet number spike ${ }^{-1}$ (Table $3)$. The differences in these traits were mainly attributed to the genotypes' capability to assimilate photosynthetic substances and vegetative growth and reflected increased responsiveness to the applied agricultural practices (Mansour et al., 2017, Abaza et al., 2020, Moustafa et al., 2021). Correspondingly, these cultivars displayed significant differences in all yield components, grain yield, and biological yield in both seasons (Table 4). 'Sakha-95' displayed the highest spike number $\mathrm{m}^{-2}, 1000$-grain weight, and grain yield. 'Shandawel-1' produced the highest grain number spike ${ }^{-1}$. 'Sids-14' and 'Sakha-95' displayed the highest biological yield. 'Sakha-95', followed by 'Sids-14', presented vigorous growth and strong enhancement in certain yield components and grain yield.

A significant interaction effect between wheat cultivars and $P$ levels was observed for flag leaf area and spike length (Table 3). 'Sids-14' exhibited the highest flag leaf area and spike length at high $P$ levels (70 kg $\mathrm{P}_{2} \mathrm{O}_{5} \mathrm{ha}^{-1}$ ), whereas 'Sakha-95' displayed the lowest value under the control treatment (Figures $1 \mathrm{~A}$ and $\mathrm{B}$ ). Moreover, a significant interaction 
Table 3. Effect of $\mathrm{P}$ levels and $\mathrm{N}$ forms on the yield attributes of three wheat cultivars during two growing seasons in 20172018 and 2018-2019.

\begin{tabular}{|c|c|c|c|c|c|c|c|c|}
\hline \multirow{2}{*}{ Studied factors } & \multicolumn{2}{|c|}{$\begin{array}{c}\text { Flag leaf area } \\
\left(\mathrm{cm}^{2}\right)\end{array}$} & \multicolumn{2}{|c|}{$\begin{array}{l}\text { Plant height } \\
(\mathrm{cm})\end{array}$} & \multicolumn{2}{|c|}{$\begin{array}{l}\text { Spike length } \\
(\mathrm{cm})\end{array}$} & \multicolumn{2}{|c|}{$\begin{array}{c}\text { Number of spikelets } \\
\text { spike }^{-1}\end{array}$} \\
\hline & $\begin{array}{c}\text { 1st } \\
\text { Season }\end{array}$ & $\begin{array}{c}\text { 2nd } \\
\text { season }\end{array}$ & $\begin{array}{c}\text { 1st } \\
\text { Season }\end{array}$ & $\begin{array}{c}\text { 2nd } \\
\text { season }\end{array}$ & $\begin{array}{c}\text { 1st } \\
\text { season }\end{array}$ & $\begin{array}{c}\text { 2nd } \\
\text { season }\end{array}$ & $\begin{array}{c}\text { 1st } \\
\text { season }\end{array}$ & $\begin{array}{c}\text { 2nd } \\
\text { season }\end{array}$ \\
\hline \multicolumn{9}{|l|}{ Phosphorus level $(P)$} \\
\hline Without & $39.83^{b}$ & $48.11^{\mathrm{c}}$ & $110.3^{a b}$ & $115.4^{b}$ & 11.31 & 11.24 & $20.90^{b}$ & $20.10^{a b}$ \\
\hline $35 \mathrm{~kg} \mathrm{P}_{2} \mathrm{O}_{5} \mathrm{ha}^{-1}$ & $41.42^{a b}$ & $50.12^{b}$ & $109.8^{b}$ & $115.1^{b}$ & 11.41 & 11.32 & $21.35^{a b}$ & $19.65^{b}$ \\
\hline $70 \mathrm{~kg} \mathrm{P} \mathrm{O}_{5} \mathrm{ha}^{-1}$ & $42.76^{a}$ & $54.57^{a}$ & $111.9^{a}$ & $116.5^{a}$ & 11.61 & 12.04 & $21.59^{a}$ & $20.79^{a}$ \\
\hline \multicolumn{9}{|l|}{ Cultivar (C) } \\
\hline Shandawel-1 & $37.27^{c}$ & $46.71^{c}$ & $106.5^{b}$ & $110.3^{b}$ & $11.55^{a}$ & $11.77^{a b}$ & $22.20^{a}$ & $20.69^{a}$ \\
\hline Sids-14 & $41.06^{b}$ & $49.23^{b}$ & $113.7^{a}$ & $118.9^{a}$ & $11.82^{a}$ & $11.82^{a}$ & $19.94^{b}$ & $18.74^{b}$ \\
\hline Sakha-95 & $45.70^{a}$ & $56.86^{a}$ & $111.8^{a}$ & $117.8^{a}$ & $10.96^{b}$ & $11.01^{b}$ & $21.69^{a}$ & $21.10^{a}$ \\
\hline \multicolumn{9}{|l|}{ Nitrogen form (N) } \\
\hline Urea & 41.17 & 50.19 & $109.8^{b}$ & $115.6^{a b}$ & 11.35 & 11.58 & 21.23 & 20.19 \\
\hline Ammonium sulfate & 40.91 & 51.61 & $111.1^{\mathrm{a}}$ & $115.1^{b}$ & 11.55 & 11.66 & 21.23 & 20.45 \\
\hline Ammonium nitrate & 41.94 & 50.99 & $111.0^{a}$ & $116.4^{a}$ & 11.42 & 11.36 & 21.38 & 19.90 \\
\hline ANOVA & $P$-value & & & & & & & \\
\hline$P$ & 0.013 & 0.001 & 0.047 & 0.041 & 0.240 & 0.099 & 0.036 & 0.045 \\
\hline C & $<0.001$ & $<0.001$ & $<0.001$ & $<0.001$ & 0.001 & 0.001 & 0.001 & 0.001 \\
\hline $\mathrm{N}$ & 0.402 & 0.386 & 0.044 & 0.035 & 0.314 & 0.156 & 0.645 & 0.090 \\
\hline$P \times C$ & 0.031 & 0.011 & 0.145 & 0.062 & 0.010 & 0.036 & 0.090 & 0.051 \\
\hline$P \times N$ & 0.463 & 0.602 & 0.332 & 0.458 & 0.319 & 0.705 & 0.152 & 0.939 \\
\hline$C \times N$ & 0.073 & 0.143 & 0.523 & 0.409 & 0.313 & 0.350 & 0.262 & 0.063 \\
\hline$P \times C \times N$ & 0.023 & 0.016 & 0.001 & 0.025 & 0.192 & 0.203 & 0.059 & 0.327 \\
\hline
\end{tabular}

\footnotetext{
Means followed by different letters under the same factor are significantly different at $P \leq 0.05$ as determined through the LSD test.
} 
Table 4. Impact of $\mathrm{P}$ levels and $\mathrm{N}$ forms on yield components, grain yield, and biological yield of three wheat cultivars during two growing seasons in 2017-2018 and 2018-2019.

\begin{tabular}{|c|c|c|c|c|c|c|c|c|c|c|}
\hline \multirow{2}{*}{ Studied factors } & \multicolumn{2}{|c|}{$\begin{array}{c}\text { Spike number } \\
\mathrm{m}^{-2}\end{array}$} & \multicolumn{2}{|c|}{$\begin{array}{c}\text { Grain number } \\
\text { spike }^{-1}\end{array}$} & \multicolumn{2}{|c|}{$\begin{array}{c}\text { 1000-grain weight } \\
\text { (g) }\end{array}$} & \multicolumn{2}{|c|}{$\begin{array}{l}\text { Grain yield } \\
\left(\mathrm{kg} \mathrm{ha}^{-1}\right)\end{array}$} & \multicolumn{2}{|c|}{$\begin{array}{l}\text { Biological yield } \\
\left(\mathrm{kg} \mathrm{ha}^{-1}\right)\end{array}$} \\
\hline & $\begin{array}{c}1 \text { st } \\
\text { season }\end{array}$ & $\begin{array}{c}\text { 2nd } \\
\text { season }\end{array}$ & $\begin{array}{c}1 \text { st } \\
\text { season }\end{array}$ & $\begin{array}{c}\text { 2nd } \\
\text { season }\end{array}$ & $\begin{array}{c}1 \text { st } \\
\text { season }\end{array}$ & $\begin{array}{c}2 \mathrm{nd} \\
\text { season }\end{array}$ & $\begin{array}{c}1 \text { st } \\
\text { season }\end{array}$ & $\begin{array}{c}\text { 2nd } \\
\text { season }\end{array}$ & $\begin{array}{c}1 \text { st } \\
\text { season }\end{array}$ & $\begin{array}{c}2 \mathrm{nd} \\
\text { season }\end{array}$ \\
\hline \multicolumn{11}{|l|}{ Phosphorus level $(P)$} \\
\hline Without & $440.2^{c}$ & $434.0^{c}$ & $63.70^{b}$ & $61.42^{c}$ & $39.52^{c}$ & $40.15^{c}$ & $7622^{c}$ & $7969^{c}$ & $19641^{c}$ & $20643^{c}$ \\
\hline $35 \mathrm{~kg} \mathrm{P}_{2} \mathrm{O}_{5} \mathrm{ha}^{-1}$ & $449.2^{b}$ & $441.1^{b}$ & $64.61^{b}$ & $64.29^{b}$ & $41.33^{b}$ & $41.56^{b}$ & $8019^{b}$ & $8621^{b}$ & $20098^{b}$ & $21736^{b}$ \\
\hline $70 \mathrm{~kg} \mathrm{P} \mathrm{O}_{5} \mathrm{ha}^{-1}$ & $462.5^{a}$ & $479.0^{a}$ & $67.47^{a}$ & $68.72^{a}$ & $44.70^{a}$ & $44.71^{a}$ & $8293^{a}$ & $8751^{a}$ & $21031^{a}$ & $22591^{a}$ \\
\hline \multicolumn{11}{|l|}{ Cultivar (C) } \\
\hline Shandawel-1 & $442.8^{b}$ & $457.1^{a}$ & $67.26^{a}$ & $67.17^{a}$ & $39.45^{c}$ & $39.87^{c}$ & $7359^{c}$ & $7876^{c}$ & $19467^{b}$ & $20450^{b}$ \\
\hline Sids-14 & $418.9^{c}$ & $437.9^{b}$ & $64.15^{b}$ & $62.88^{c}$ & $41.54^{b}$ & $42.17^{b}$ & $8279^{b}$ & $8438^{b}$ & $20774^{a}$ & $22865^{a}$ \\
\hline Sakha-95 & $490.1^{a}$ & $459.1^{a}$ & $64.37^{b}$ & $64.38^{b}$ & $44.57^{a}$ & $44.38^{a}$ & $8629^{a}$ & $9027^{\mathrm{a}}$ & $20531^{a}$ & $21653^{a}$ \\
\hline \multicolumn{11}{|l|}{ Nitrogen form (N) } \\
\hline Urea & $435.1^{c}$ & $444.7^{b}$ & 65.41 & 65.81 & $41.52^{a}$ & $42.55^{a}$ & 7895 & 8408 & 20053 & 21696 \\
\hline Ammonium sulfate & $466.3^{a}$ & $449.8^{a b}$ & 65.54 & 64.50 & $39.90^{b}$ & $40.80^{b}$ & 8113 & 8498 & 20353 & 21655 \\
\hline Ammonium nitrate & $450.4^{b}$ & $459.7^{a}$ & 64.83 & 64.12 & $42.40^{a}$ & $43.07^{a}$ & 7927 & 8435 & 20365 & 21617 \\
\hline ANOVA & $P$-value & & & & & & & & & \\
\hline$P$ & $<0.001$ & $<0.001$ & 0.015 & 0.001 & $<0.001$ & $<0.001$ & 0.029 & 0.001 & 0.028 & 0.001 \\
\hline C & $<0.001$ & 0.001 & 0.033 & 0.001 & $<0.001$ & $<0.001$ & $<0.001$ & $<0.001$ & 0.003 & 0.001 \\
\hline $\mathrm{N}$ & 0.001 & 0.011 & 0.828 & 0.179 & 0.001 & 0.001 & 0.489 & 0.712 & 0.501 & 0.956 \\
\hline$P \times C$ & 0.003 & 0.020 & $<0.001$ & $<0.001$ & $<0.001$ & $<0.001$ & 0.835 & 0.425 & 0.017 & 0.013 \\
\hline$P \times N$ & $<0.001$ & $<0.001$ & 0.788 & 0.570 & $<0.001$ & $<0.001$ & 0.024 & 0.018 & 0.651 & 0.502 \\
\hline $\mathrm{C} \times \mathrm{N}$ & $<0.001$ & $<0.001$ & 0.076 & 0.332 & 0.001 & 0.014 & 0.028 & 0.034 & 0.144 & 0.786 \\
\hline $\mathrm{P} \times \mathrm{C} \times \mathrm{N}$ & 0.002 & 0.042 & $<0.001$ & $<0.001$ & $<0.001$ & $<0.001$ & 0.270 & 0.208 & 0.623 & 0.387 \\
\hline
\end{tabular}

Means followed by different letters under the same factor are significantly different at $P \leq 0.05$ as determined through the LSD test. 

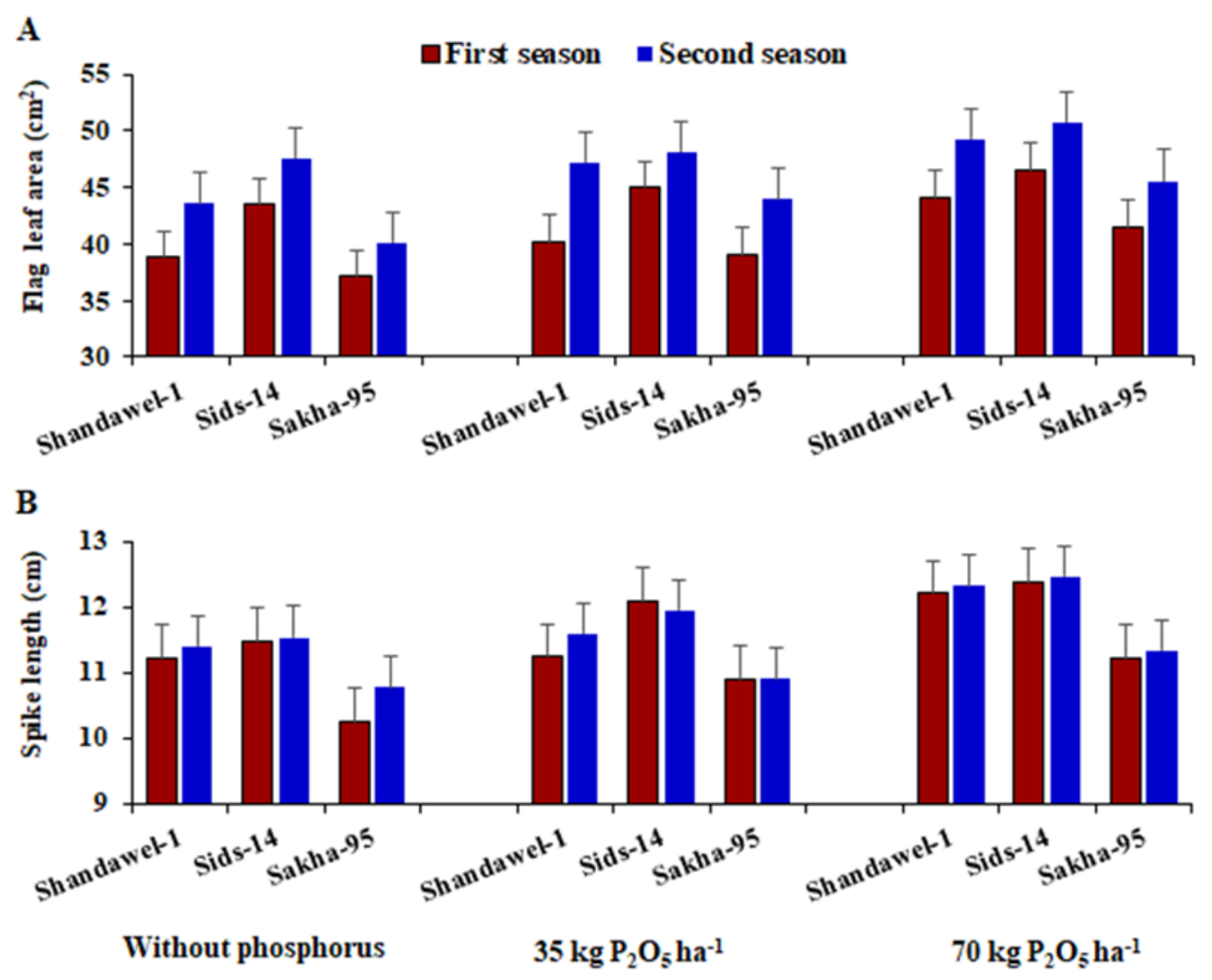

Figure 1. Influence of $P$ levels on the flag leaf area (A) and spike length (B) of three wheat cultivars during two growing seasons in 2017-2018 and 2018-2019. The bars on the columns represent the LSD $(P<0.05)$.

effect was detected for the spike number $\mathrm{m}^{-2}$, the grain number spike ${ }^{-1}, 1000$-grain weight, and biological yield (Table 4). The uppermost spike number $\mathrm{m}^{-2}$ was obtained by 'Sakha-95' at high $P$ levels, whereas the lowest was observed in 'Sids14 ' under the control treatment (Figure 2A). 'Shandawel-1' had the highest grain number spike ${ }^{-1}$ at high $P$ levels, whereas 'Sakha-95' recorded the lowest number under the nonadded $P$ control treatment (Figure 2B). 'Sakha-95' exhibited the heaviest 1000 -grain weight under high $P$ levels, whereas 'Shandawel-1' showed the lowest seed index under the nonadded $P$ control treatment (Figure 2C). 'Sakha-95' exhibited the highest biological yield under a high $P$ level, whereas 'Shandawel-1' presented the lowest value under the nonadded $P$ control treatment (Figure 2D). Correspondingly, Yaseen and Hussain
(2000), Yan et al. (2010), McDonald et al. (2015), Bilal et al. (2018), and Meier et al. (2021) recorded similar genotypic variations in yield traits under different $P$ levels.

\section{Effect of $\mathbf{N}$ forms on the evaluated traits}

In both seasons, the forms of $\mathrm{N}$ fertilizer did not significantly affect all evaluated traits, except for plant height, spike number $\mathrm{m}^{-2}$, and 1000-grain weight (Tables 3 and 4 ). The highest plant height was obtained under ammonium nitrate treatment followed by that under ammonium sulfate treatment. Similarly, the use of ammonium-containing fertilizer (ammonium sulfate and ammonium nitrate) efficiently increased spike number $\mathrm{m}^{-2}$ and 1000-grain weight. Moreover, 

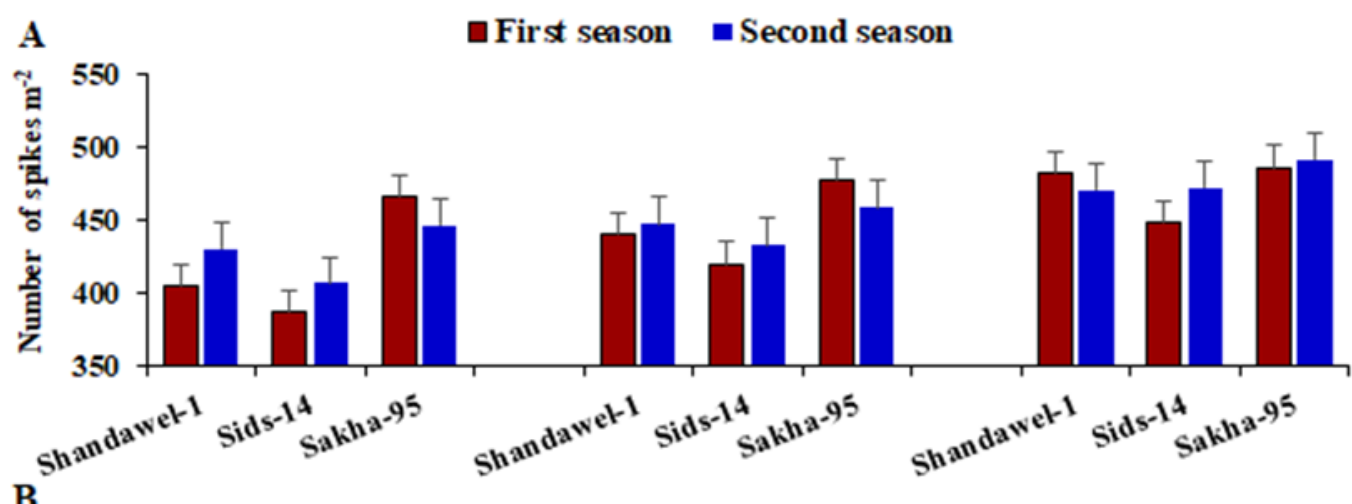

B
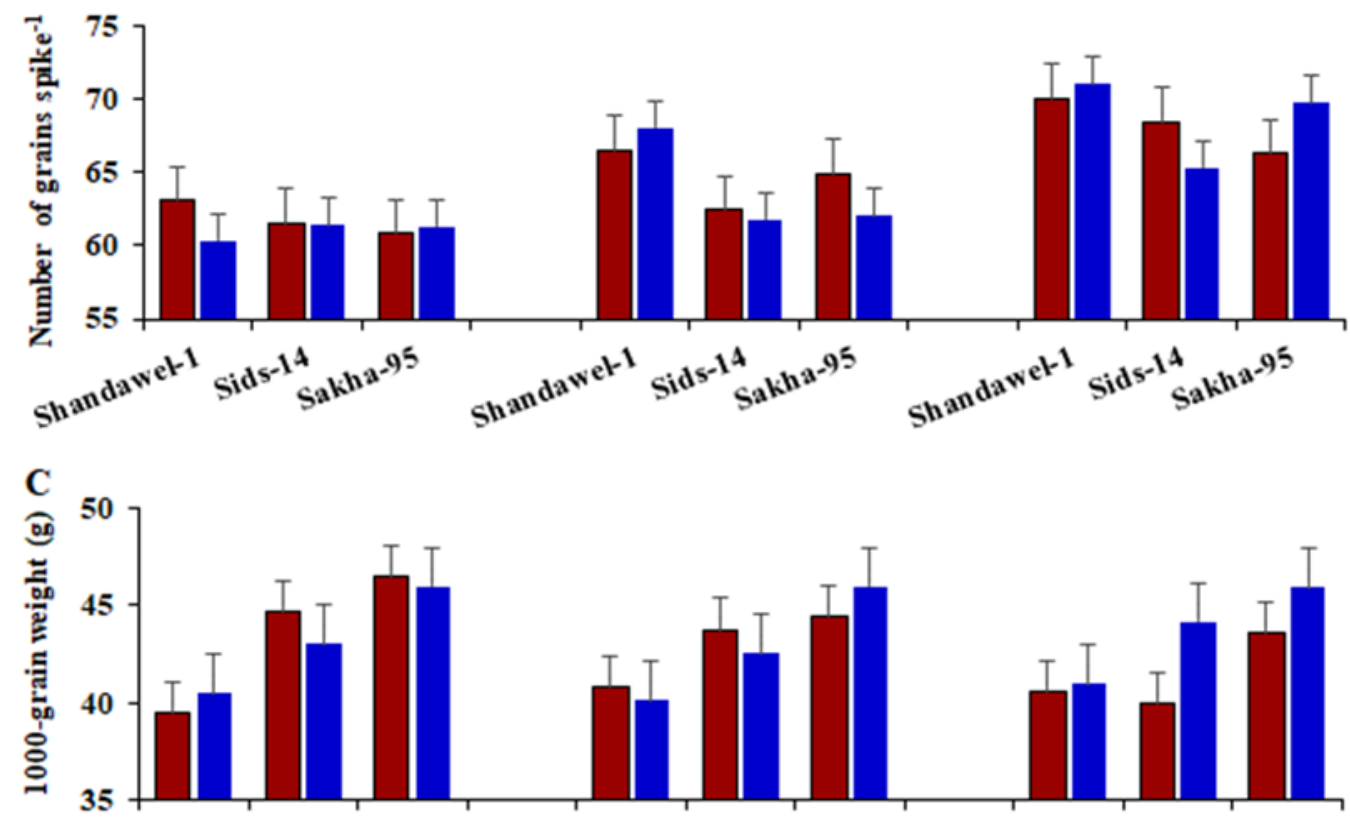

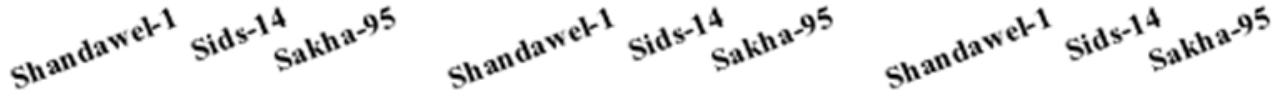

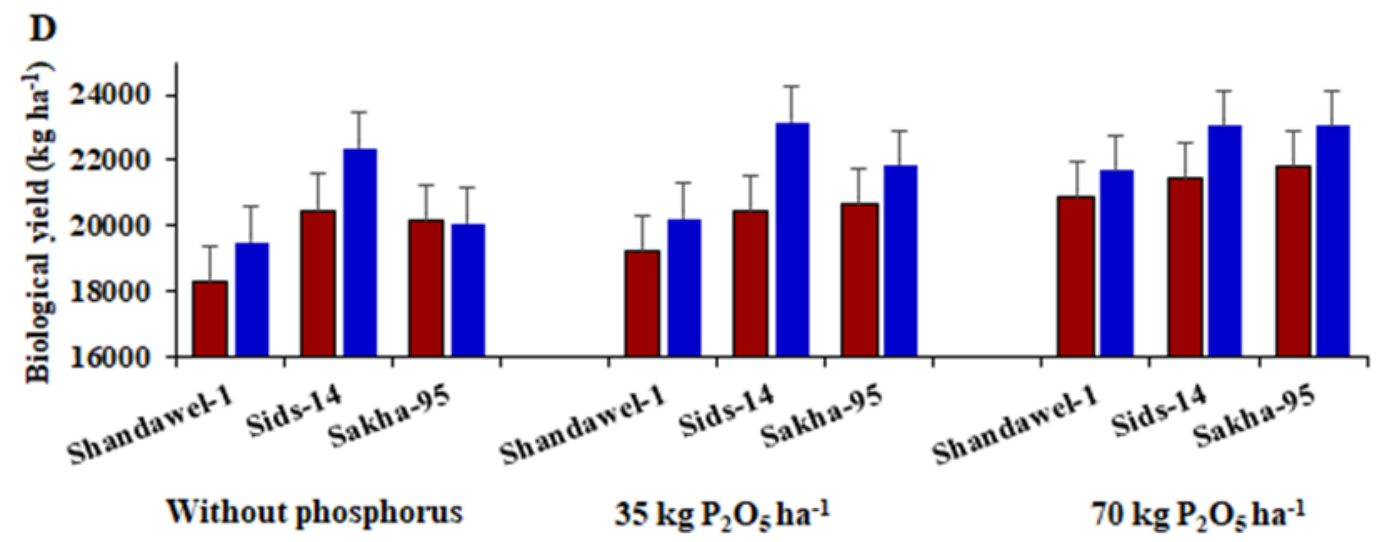

Figure 2. Influence of $P$ levels on the spike number $\mathrm{m}^{-2}$, grain number spike ${ }^{-1}, 1000$-grain weight, and biological yield of three wheat cultivars during two growing seasons in 20172018 and 2018-2019. The bars on the columns represent the LSD $(P<0.05)$. 
Swailam et al. (2021)

ammonium sulfate resulted in the highest grain yield with nonsignificant differences compared with the other two forms. The higher yield attributes under treatment with ammonium sulfate and ammonium nitrate than those under urea could be attributed to increased $\mathrm{N}$ use efficiency as deduced by Amanullah et al. (2016). Moreover, Chien et al. (2011) and Hafez and Kobata (2012) reported that ammonium sulfate has potential advantages over other forms due to its higher transportation charges and free sulfur content (24\%). Furthermore, ammonium nitrate has the benefit of containing two different $\mathrm{N}$ sources, namely, ammonium and nitrate, and thus prolonged $\mathrm{N}$ availability when compared with urea (Amanullah et al., 2016).

The interaction between $\mathrm{N}$ form and $P$ level was not significant for all studied traits except for spike number $\mathrm{m}^{-2}, 1000$-grain weight, and grain yield (Table 3 and 4 ). The highest spike number $\mathrm{m}^{-2}$ was found under high $P$ levels and ammonium sulfate or ammonium nitrate treatment, whereas the lowest number was obtained under the nonadded $P$ control and urea treatment (Figure $3 \mathrm{~A}$ ). The highest 1000 -grain weight and grain yield were obtained by using high $P$ levels and ammonium sulfate, whereas the lowest seed index and grain yield were recorded under the nonadded control and urea treatment (Figures $3 \mathrm{~B}$ and $\mathrm{C}$ ).

The interaction between $\mathrm{N}$ form and wheat cultivar was not significant for all tested traits, except for spike number $\mathrm{m}^{-2}, 1000$-grain weight and grain yield. The highest spike number $\mathrm{m}^{-2}$ was produced by 'Sakha-95' under ammonium nitrate and sulfate fertilization, whereas the lowest number was shown by 'Sids-14' under urea treatment (Figure 4A). The heaviest 1000 -grain weight was exhibited by 'Sids-14' under ammonium sulfate treatment, whereas the lowest seed index was recorded by the same cultivar treated with urea (Figure 4B). The highest grain yield was produced by 'Sakha-95' under ammonium sulfate or ammonium nitrate treatment, whereas the lowest value was shown by 'Shandawel-1' under urea treatment (Figure 4C).

\section{Grain yield response and $P$ use efficiency}

The relationship between $P$ level and the grain yield of the assessed wheat cultivars is illustrated in Figure 5A. 'Sakha-95', followed by 'Sids-14' produced higher grain yields under the same $P$ levels than the other cultivars (Figure 5A). Moreover, the regression equation revealed that under $P$ deficiency (nonadded control), 'Sakha-95' consistently produced higher grain yields ( $8523 \mathrm{~kg} \mathrm{ha}^{-1}$ ) than the other two cultivars. Likewise, the agronomic $P$ use efficiency differed considerably among the evaluated cultivars under the $P$ levels of 35 and $70 \mathrm{~kg} \mathrm{P}_{2} \mathrm{O}_{5}$ ha $^{-1}$ (Figure 5B). The maximum APUE was shown by 'Sakha-95' under both $P$ levels. APUE declined with the increase in $P$ level, whereas the cultivars exhibited different reduction tendencies with the increase in $P$ level. The lowest APUE was recorded for 'Shandawel-1' under the intermediate $P$ level and for 'Sids-14' under the high $P$ level. The obtained results indicated that 'Sakha-95' used $P$ efficiently and had good abilities to progress vegetative growth, resulting in the increment in grain and biological yields. Consequently, the commercial use of cultivars with increased $P$ use efficiency is recommended. Moreover, these genotypes could be utilized in wheat breeding programs to improve $P$ use efficiency. Similar results for the significant differences among wheat genotypes in APUE at different $P$ levels have been reported other researchers in the past (Ozturk et al., 2005; Yaseen and Malhi, 2009; Bilal et al., 2018; Deng et al., 2018; Meier et al., 2021).

\section{Interrelationship among evaluated traits and treatments}

PCA was performed to study the relationship among the tested traits and treatments (Figure 6). The first two PCAs 

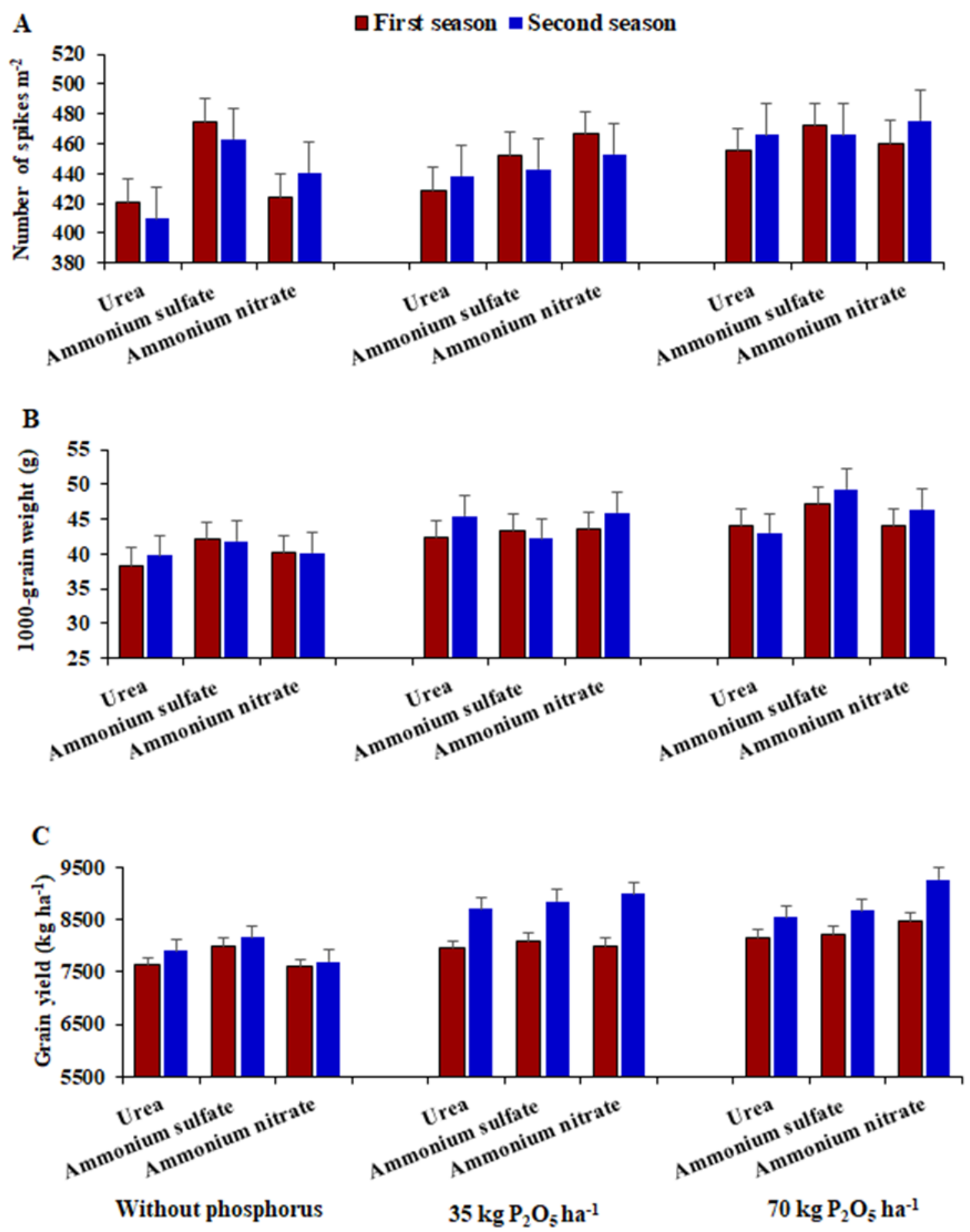

Figure 3. Influence of $\mathrm{P}$ levels and $\mathrm{N}$ forms on spike number $\mathrm{m}^{-2}, 1000$-grain weight, and grain yield during two growing seasons in 2017-2018 and 2018-2019. The bars on the columns represent the LSD $(P<0.05)$. 

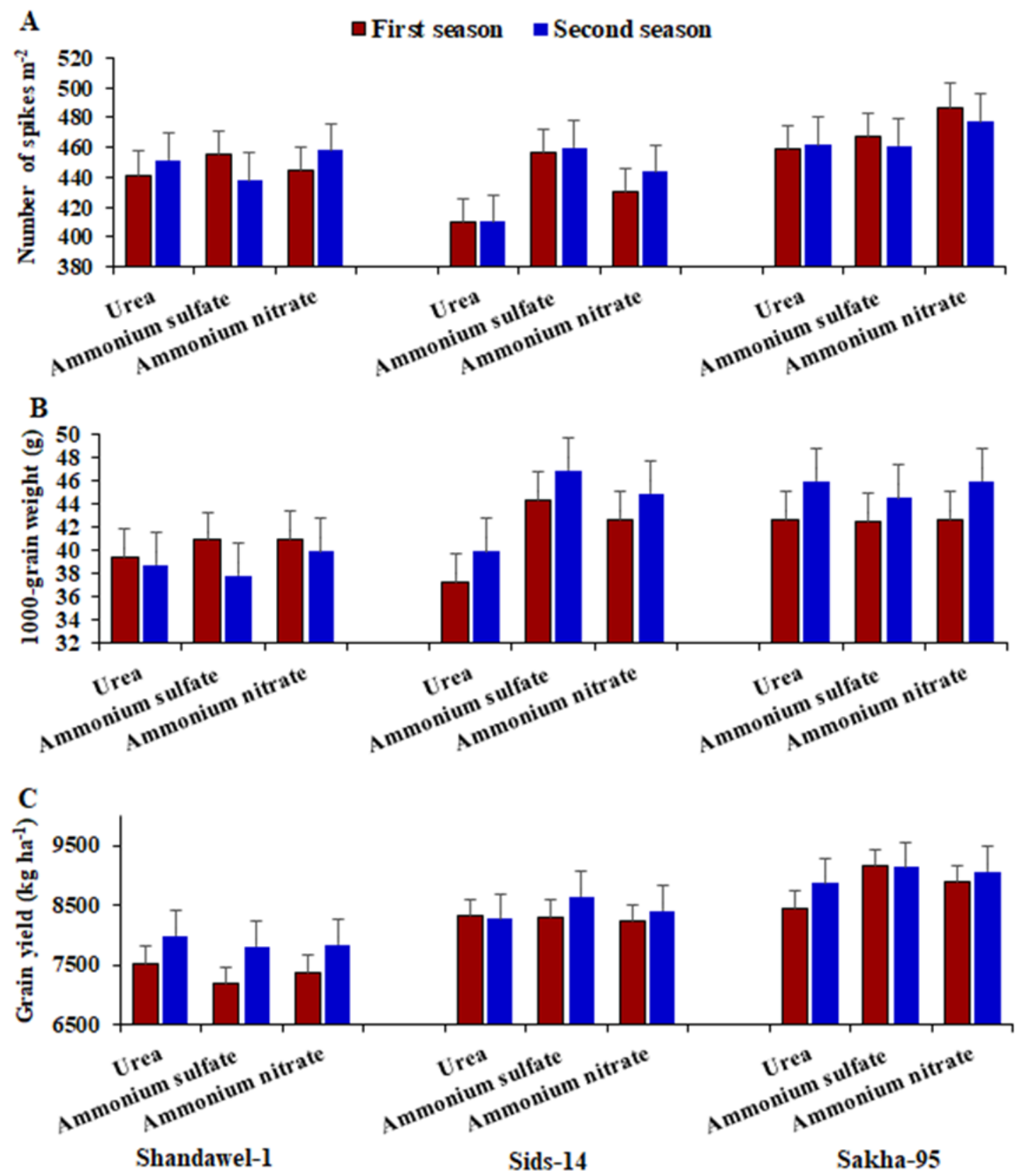

Figure 4. Influence of $\mathrm{N}$ forms on the spike number $\mathrm{m}^{-2}, 1000$-grain weight, and grain yield of three wheat cultivars during two growing seasons in 2017-2018 and 2018-2019. The bars on the columns represent the LSD $(P<0.05)$. 


\section{A}<smiles>C[13CH][13CH][AsH]C</smiles>

- Sids-14

- Sakha-95

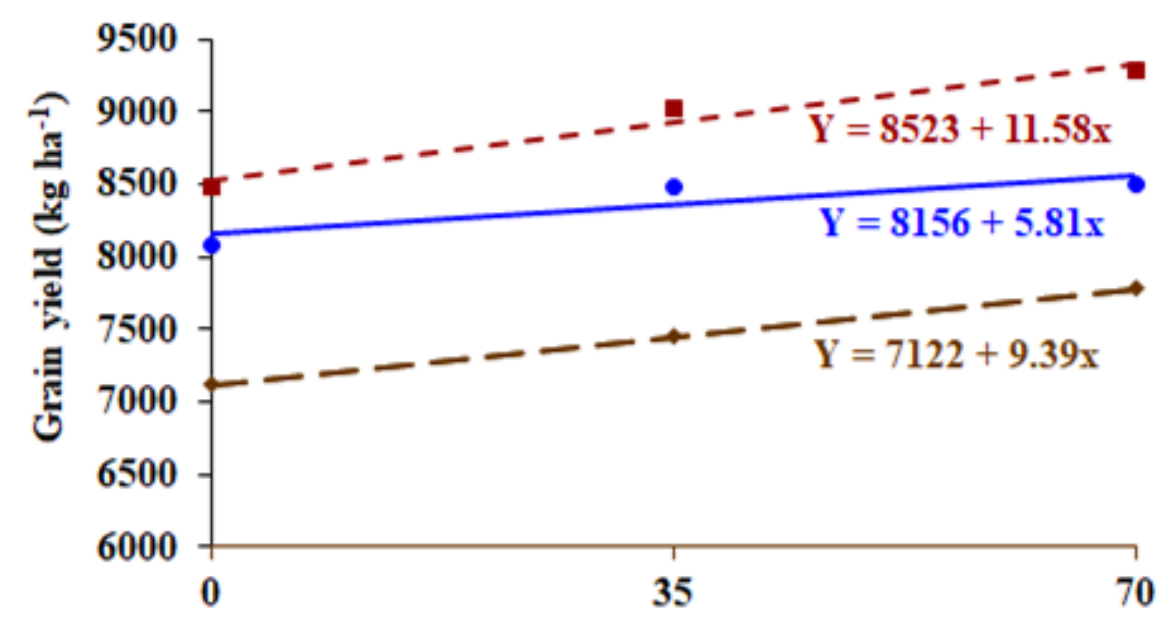

B

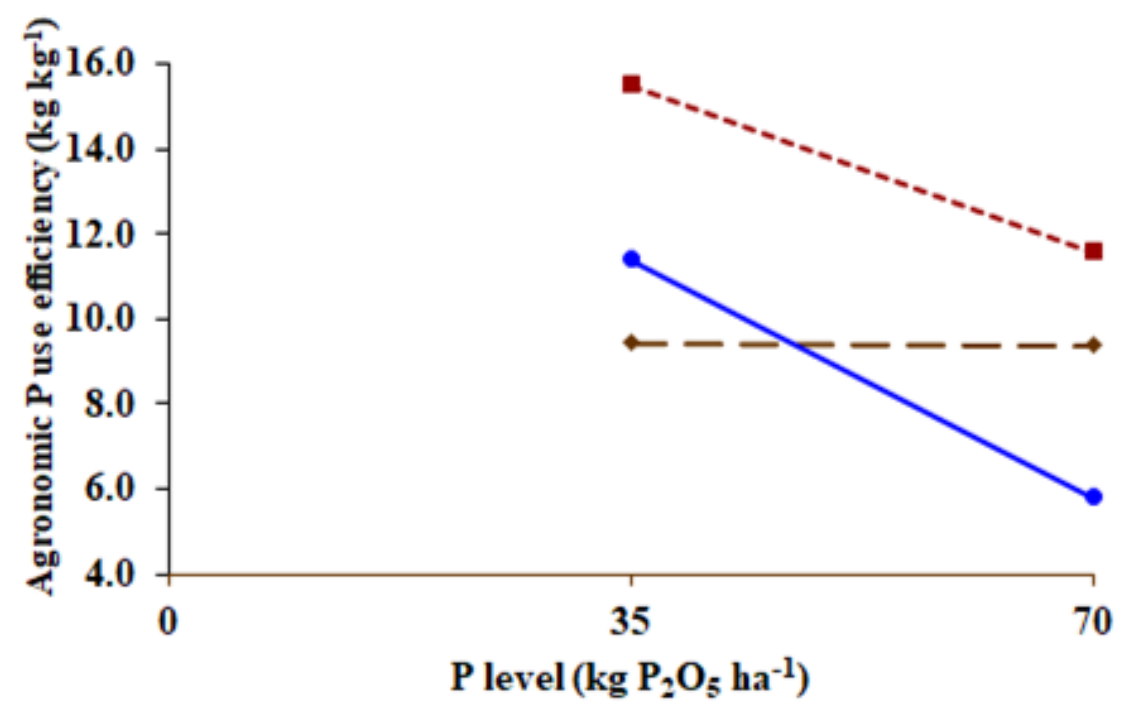

Figure 5. Grain yield response to $P$ fertilization $(A)$ and agronomic $P$ use efficiency (kg grain $\left.\mathrm{kg}^{-1} \mathrm{P}\right)(B)$ of the evaluated cultivars averaged over two seasons. 


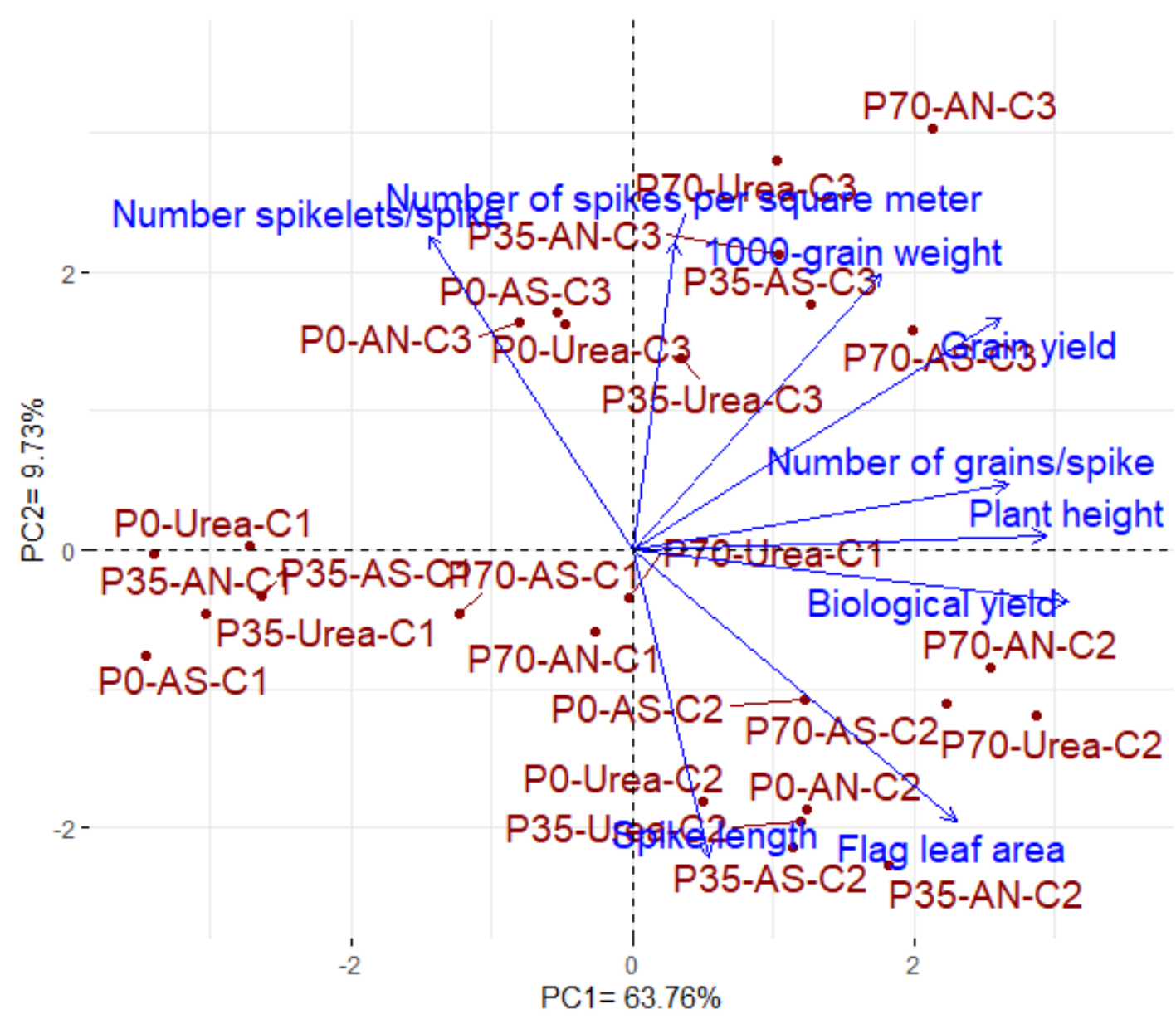

Figure 6. PCA biplot for the evaluated traits of wheat cultivars (C1: 'Shandawel-1', C2: 'Sids-14' and C3: 'Sakha-95') under three P levels (P0, P35, and P70 kg $\mathrm{P}_{2} \mathrm{O}_{5} \mathrm{ha}^{-1}$ ) and three $\mathrm{N}$ forms (AS: ammonium sulfate, AN: ammonium nitrate, and urea) over two seasons.

accounted for $73.49 \%$ of the variability. PCA1 explained $63.76 \%$ of the variation and appeared to be associated with the increase in $P$ level from zero on the negative side to $70 \mathrm{~kg} \mathrm{P}_{2} \mathrm{O}_{5} \mathrm{ha}^{-1}$ on the positive side (Figure 6). PCA2 accounted for $9.73 \%$ of the variation and appeared to be related to wheat cultivars from the top with C3 ('Sakha-95') to the bottom with C2 ('Sids-14'). 'Sakha-95' (C3) under $70 \mathrm{~kg} \mathrm{P}_{2} \mathrm{O}_{5} \mathrm{ha}^{-1}$ and ammonium sulfate use (P70-AS-C3) were located near grain yield, thus reinforcing the above results. The angles among trait vectors illustrated the association among the studied traits. Contiguous vectors reflect a strong positive correlation, whereas vectors with large angles (approximately $180^{\circ}$ ) reveal a negative correlation. A strong positive association was identified among grain yield and all its attributes. The closest components to grain yield were 1000grain weight and grain number per spike, reflecting their importance in indirect selection due to the ease of their measurement. A similar strong association among grain yield, 1000-grain weight, and grain number per spike was reported by Iftikhar et al. (2012), Poudel et al. (2017), Kamara et al. (2021), and Gharib et al. (2021) 


\section{CONCLUSIONS}

$\mathrm{P}$ and $\mathrm{N}$ management is one of the most important factors influencing wheat production, particularly under semiarid environments. The findings of this study revealed a significant increment in all traits, except for spike length, with the increase in $P$ level. The highest values of all of the studied agronomic traits were obtained under high $P$ values $\left(70 \mathrm{~kg} \mathrm{P}_{2} \mathrm{O}_{5}\right.$ $\left.\mathrm{ha}^{-1}\right)$. The evaluated wheat cultivars displayed significant differences in all traits. 'Sakha-95' displayed the highest grain and biological yields, followed by 'Sids-14'. Furthermore, as indicated by its agronomic $P$ use efficiency, 'Sakha-95' used $P$ more efficiently than the other cultivars. Therefore, this cultivar could be used commercially and exploited in wheat breeding programs to improve $P$ use efficiency. In general, the obtained results revealed that $\mathrm{N}$ forms had a marginally substantial effect on grain yield and its attributes. Accordingly, applying ammonium sulfate for wheat production on soils with moderate $\mathrm{pH}$ is unaffordable due to its high cost.

\section{REFERENCES}

Abaza GMSM, Awaad HA, Attia ZM, Abdel-lateif KS, Gomaa MA, Abaza SMSM, Mansour $E$ (2020). Inducing potential mutants in bread wheat using different doses of certain physical and chemical mutagens. Plant Breed. Biotechnol. 8: 252-264.

Amanullah A (2014). Source and rate of nitrogen application influence agronomic $\mathrm{N}$-use efficiency and harvest index in maize (Zea mays L) genotypes. Maydica 59: 80-89.

Amanullah A, Inamullah I (2016). Residual phosphorus and zinc influence wheat productivity under rice-wheat cropping system. Springerplus 5: 255.

Amanullah A, Iqbal A, Ali A, Fahad S, Parmar B (2016). Nitrogen source and rate management improve maize productivity of smallholders under semiarid climates. Front. Plant Sci. 7: 1773.
Amin MEH (2011). Effect of different nitrogen sources on growth, yield and quality of fodder maize (Zea mays L.). J. Saudi Soc. Agric. Sci. 10: 17-23.

Assefa S, Haile W, Tena W (2021). Effects of phosphorus and sulfur on yield and nutrient uptake of wheat (Triticum aestivum L.) on Vertisols, North Central, Ethiopia. Heliyon 7: e06614.

Attia A, El-Hendawy S, Al-Suhaibani N, Tahir MU, Mubushar M, dos Santos Vianna M, Ullah H, Mansour E, Datta A (2021). Sensitivity of the DSSAT model in simulating maize yield and soil carbon dynamics in arid Mediterranean climate: Effect of soil, genotype and crop management. Field Crops Res. 260: 107981.

Baker A, Ceasar SA, Palmer AJ, Paterson JB, Qi W, Muench SP, Baldwin SA (2015). Replace, reuse, recycle: improving the sustainable use of phosphorus by plants. J. Exp. Bot. 66: 3523-3540.

Bilal HM, Aziz T, Maqsood MA, Farooq M, Yan G (2018). Categorization of wheat genotypes for phosphorus efficiency. PloS One 13: e0205471.

Biswas DK, Ma BL (2016). Effect of nitrogen rate and fertilizer nitrogen source on physiology, yield, grain quality, and nitrogen use efficiency in corn. Can. J. Plant Sci. 96: 392-403.

Chien SH, Gearhart MM, Villagarcía S (2011). Comparison of ammonium sulfate with other nitrogen and sulfur fertilizers in increasing crop production and minimizing environmental impact: A review. Soil Sci. 176: 327-335.

Deng $\mathrm{Y}$, Teng $\mathrm{W}$, Tong $\mathrm{Y}$, Chen $\mathrm{X}$, Zou C (2018). Phosphorus efficiency mechanisms of two wheat cultivars as affected by a range of phosphorus levels in the field. Front. Plant Sci. 9: 1614.

FAO-STAT (2021). Food and Agriculture Organization of the United Nations. Statistical Database. Availabe online: http://www.fao.org/faostat/en/\#data (accessed on 22 August 2021).

Gharib MAAH, Qabil N, Salem AH, Ali MMA, Awaad HA, Mansour E (2021). Characterization of wheat landraces and commercial cultivars based on morpho-phenological and agronomic traits. Cereal Res. Commun. 49: 149159.

Gracia M, Mansour E, Casas A, Lasa J, Medina B, Cano JLM, Moralejo M, López A, Fuster PL, Escribano J (2012). Progress 
in the Spanish national barley breeding program. Span. J. Agric. Res. 10(3): 741-751.

Guo C, Li P, Lu J, Ren T, Cong R, Li X (2016). Application of controlled-release urea in rice: Reducing environmental risk while increasing grain yield and improving nitrogen use efficiency. Commun. in Soil Sci. Plant Anal. 47: 1176-1183.

Hafez EMM, Kobata T (2012). The effect of different nitrogen sources from urea and ammonium sulfate on the spikelet number in Egyptian spring wheat cultivars on well watered pot soils. Plant Prod. Sci. 15: 332-338.

Halvorson AD, Del Grosso SJ, Alluvione $F$ (2010). Nitrogen source effects on nitrous oxide emissions from irrigated no-till corn. J. Environ. Qual. 39: 15541562.

He P, Li S, Jin J, Wang H, Li C, Wang Y, Cui R (2009). Performance of an optimized nutrient management system for double-cropped wheat - maize rotations in North Central China. Agron. J. 101: 1489-1496.

Iftikhar R, Khaliq I, Ijaz M, Rashid MAR (2012). Association analysis of grain yield and its components in spring wheat (Triticum aestivum L.). Am. Eur. J. Sustain. Agric. 12: 389-392.

Kamara MM, Ibrahim KM, Mansour E, Kheir A, Germoush MO, El-Moneim A, Motawei MI, Alhusays AY, Farid MA, Rehan M (2021). combining ability and gene action controlling grain yield and its related traits in bread wheat under heat stress and normal conditions. Agron. 11: 1450.

Khan A (2015). Phosphorus and compost management influence maize (Zea mays) productivity under semiarid condition with and without phosphate solubilizing bacteria. Front. Plant Sci. 6: 1083.

Li A, Hu B, Chu C (2021). Epigenetic regulation in nitrogen and phosphorus responses of plants. J. Plant Physiol. 153363: 258-259.

Ma B, Wu T, Tremblay N, Deen W, McLaughlin N, Morrison M, Stewart G (2010). Onfarm assessment of the amount and timing of nitrogen fertilizer on ammonia volatilization. Agron. J. 102: 134-144.

Majeed MA, Ahmad R, Tahir M, Tanveer A, Ahmad M (2014). Effect of phosphorus fertilizer sources and rates on growth and yield of wheat (Triticum aestivum L.). Asian. J. Agric. Biol. 2: 14-19.

Mansour E, Merwad A, Yasin M, Abdul-Hamid M, El-Sobky E, Oraby H (2017). Nitrogen use efficiency in spring wheat: Genotypic variation and grain yield response under sandy soil conditions. J. Agric. Sci. 155: 1407-1423.

Mansour E, Moustafa ES, Desoky E-SM, Ali M, Yasin MA, Attia A, Alsuhaibani N, Tahir MU, El-Hendawy S (2020). Multidimensional evaluation for detecting salt tolerance of bread wheat genotypes under actual saline field growing conditions. Plants 9: 1324.

Mansour E, Moustafa ES, El-Naggar NZ, Abdelsalam A, Igartua E (2018a). Grain yield stability of high-yielding barley genotypes under Egyptian conditions for enhancing resilience to climate change. Crop Pasture Sci. 69: 681-690.

Mansour E, Moustafa ES, Qabil N, Abdelsalam A, Wafa HA, El Kenawy A, Casas AM, Igartua $E$ (2018b). Assessing different barley growth habits under Egyptian conditions for enhancing resilience to climate change. Field Crops Res. 224: 67-75.

McBeath T, McLaughlin M, Kirby J, Armstrong R (2012). The effect of soil water status on fertiliser, topsoil and subsoil phosphorus utilisation by wheat. Plant Soil 358: 337-348.

McDonald G, Bovill W, Taylor J, Wheeler R (2015). Responses to phosphorus among wheat genotypes. Crop Pasture Sci. 66: 430-444.

McKenzie $R$, Bremer $E$, Kryzanowski $L$, Middleton A, Solberg E, Heaney D, Coy G, Harapiak J (2003). Yield benefit of phosphorus fertilizer for wheat, barley and canola in Alberta. Can. J. Soil Sci. 83: 431-441.

McLaughlin MJ, McBeath TM, Smernik R, Stacey SP, Ajiboye B, Guppy C (2011). The chemical nature of $P$ accumulation in agricultural soils-implications for fertiliser management and design: an Australian perspective. Plant Soil 349: 69-87.

McMaster GS, Wilhelm W, Palic D, Porter JR, Jamieson P (2003). Spring wheat leaf appearance and temperature: extending the paradigm? Ann. Bot. 91: 697-705.

Meier S, Moore F, Morales A, Jobet C, LópezOlivari R, Aponte $\mathrm{H}$, Cartes $\mathrm{P}$, Campos $\mathrm{P}$, Khan $\mathrm{N}$ (2021). Interactive role between phosphorus utilization 
efficiency and water use efficiency. A tool to categorize wheats co-adapted to water and phosphorus limiting conditions. Agric. Water Manag. 248: 106765.

Moustafa ES, El-Sobky E-SE, Farag HI, Yasin MA, Attia A, Rady MO, Awad MF, Mansour E (2021). Sowing date and genotype influence on yield and quality of dual-purpose barley in a saltaffected arid region. Agron. 11: 717.

Ozturk L, Eker S, Torun B, Cakmak I (2005). Variation in phosphorus efficiency among 73 bread and durum wheat genotypes grown in a phosphorusdeficient calcareous soil. Plant Soil 269: 69-80.

Poudel A, Ghimire SK, Ojha BR, Acharya BD, Thapa DB (2017). Effect of Terminal drought stress on morpho-physiological and yield potential traits of bread wheat genotypes. Pak. J. Biol. Sci. 3: 72-77.

Shewry PR, Hey SJ (2015). The contribution of wheat to human diet and health. Food Energy Secur. 4: 178-202.

Simpson RJ, Oberson A, Culvenor RA, Ryan $\mathrm{MH}$, Veneklaas EJ, Lambers $\mathrm{H}$, Lynch
JP, Ryan PR, Delhaize E, Smith FA (2011). Strategies and agronomic interventions to improve the phosphorus-use efficiency of farming systems. Plant Soil 349: 89-120.

Van-Tol HM, Armbrust EV (2021). Genomescale metabolic model of the diatom Thalassiosira pseudonana highlights the importance of nitrogen and sulfur metabolism in redox balance. PloS One 16: e0241960.

Yan H, Liu W, Liu X, Li G, Zhang S (2010). Comparison of rhizosphere impacts of two wheat genotypes differing in phosphorus utilization efficiency. Can. J. Plant Sci. 90: 311-317.

Yaseen M, Hussain T (2000). Differential growth behaviour of selected wheat genotypes for phosphorus deficiency stress tolerance I: Growth characteristics. Pak. J. Biol. Sci. 3: 883-884.

Yaseen M, Malhi SS (2009). Variation in yield, phosphorus uptake, and physiological efficiency of wheat genotypes at adequate and stress phosphorus levels in soil. Commun. in Soil Sci. Plant Anal. 40: 3104-3120. 